TABLE 1.

$\begin{array}{cccc}\text { Date } & \begin{array}{c}\text { Ethyl mercury } \\ \text { phosphate }\end{array} & \text { Acenaphthene } & \text { Control } \\ \text { Sept. } & 0.14 & 0.11 & 0.07 \\ \text { " } 14 & 0.98 & 0.28 & 0.68 \\ \text { oct. } 20 & 2.34 & 1.42 & 1.32 \\ \text { 4 } & 2.97 & 1.67 & 1.82\end{array}$

Fruits of the 'mercury' series were mostly malformed and much smaller than those of the controls. An attack of mildew caused most of the fruits to be shed: but all 29 of the fruits remaining on the 'mercury' series were parthenocarpic; of the acenaphthene series 18 were parthenocarpic out of 25 , while only 2 of 29 control fruits were parthenocarpic.

To tomatoes (var. Lucullus) a 0.001 per cent solution of colchicine was administered through a cut in the stem ${ }^{5}$ and by repeatedly spraying the flowers with the solution.

More fruit was set, and earlier, in the treated than in the control plants, Results are shown in Table 2.

TABLE 2.

Total number Total weight Av. weight Number of Treatment of fruits of fruits of one fruit ripe fruits $\begin{array}{llllll}\text { Colchicine } & 46 & 1440.0 \mathrm{gm} . & 31 \cdot 3 \mathrm{gm} . & 29 \\ \text { Control } & 28 & 1105.0 \mathrm{H}, & 39.2 \mathrm{~N} & 18\end{array}$ All the treated fruits except three were parthenocarpic, but none of
the control fruits was. Lenticels of the treated plants were markedly the control fruits was. Lenticels of the treated plants were ma

hypertrophic and some treated plants had adventitious roots. In addition to giving evidence of induction of parthenocarpy by a mercury compound chemically unrelated to substances previously shown to exhibit that property, I want to stress the hormonal effects. Taken together, the flndings conflrm the suggestion ${ }^{6}$ that there is essentially a common mechanism at work, namely, a disturbance of the vertical polarity of translocation of endogeno
the hyper-compensations resulting therefrom.

Faculty of Horticulture,

Institute of Vegetable Crops

Hungarian Agricultural University, Budapest.

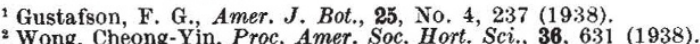

' Wong, Cheong-Yin, Proc. Amer. Soc. Hort. Sci., 36 , Bull. Hung. Agric. Univ., Fac. Hort., 11, in the press. 'Havas, L. J., Bull. Hung. Agric. Univ.,

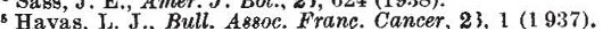

'Havas, I. J., Growth, 2, No. 3, 257 (1938).

\section{Anterior Process of the Malleus in Rodents}

A LARGE anterior process of the malleus (processus gracilis, folianus, or longus of various authors) is known to occur in Monotremata, Marsupislia, Insectivora, Edentata, and Chiroptera ${ }^{1,2}$. The process is much reduced in higher mammals ${ }^{2}$. In an investigation of the tympanic region of some mammals it was found that most Egvptian rodents possess a large anterior process of the malleus which in adult individuals completely fuses with the tympanic bone. The process is perforated for the passage of the chorda tympani and may project with a free extremity on the ventral surface of the skull between the bulla and the base of the squamosal. A very long and broad process has been found in Mus musculus (Fig. 1a), Rattus rattus, $R$. norvegicus, Acomys cahirinus, A. russatus and Arvicanthis niloticus (Murinæ). The process is short and broad in Gerbillus pyramidum (Fig. 1b), G. yerbillus, Meriones libycus, Pachyuromys duprasi and Psammomys obesus (Gerbilling). It is long and narrow in Allactaga tetradactyla, adze-shaped in Jaculus jaculus and $J$. orientalis (Dipodinæ), and is much reduced in Oryctolagus cuniculus (Leporidæ).

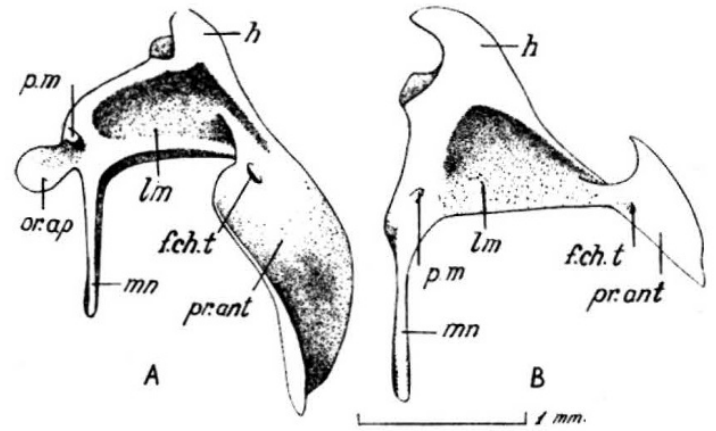

LEFT MALLECS of Mus musculus (A) AND of Gerbillus pyramidum (B). INTERNAL vIEW: f.ch.t., FORAMEN FOR CHORDA TYMPANI; h., HEAD; Im. LAMINA; mn., MANUBRIOM ; or.ap., ORBICULAR APOPHYSIS ; p.m., PROCESSUS MUSCULARIS ; pr.ant., ANTERIOR PROCESS.

Gaupp ${ }^{3}$ states that the anterior process of the malleus in mammals is formed by a dermal bone, the homologue of the reptilian gonial (prearticular), Ridewood' says that cartilage-bone enters largely into its composition, and De Beer ${ }^{5}$ expresses the view that the process is primarily a part of the malleus representing all that is left of its connexion with Meckel's eartilage, ossifying as cartilage-bone to which
the prearticular subsequently becomes fused. The results so far reached from the study of alizarin-stained specimens of a number of embryonic and post-embryonic stages of Hemiechinus (Insectivora) Rousettus and Tadarida (Chiroptera), Mus and Gerbillus (Rodentia) are in agreement with Gaupp's view. In all these genera the part of Meckel's cartilage opposite the gonial does not ossify and takes no part in the composition of the anterior process of the adult malleus which appears to be formed solely by the gonial. The process of ossification of the malleus starts in the gonial and proceeds into the lamina and head of the developing malleus; the manubrium ossifles later.

Although a gonial has been described in the embryo of Mus by Fuchs $^{6}$ and of Lepus by Voit ${ }^{7}$ no reference has been made to it in rodents' mallei so far described by various authors.

Full details of this study will be published elsewhere.

Faculty of Science,

Abbassia, Cairo.

March 16.

1 Doran, A. H. G., Trans. Lirn. Soc., 1 (1878).

2Weber, M., "Die Säugetiere", 1 (1927).

"Gaupp, E., Anat. Anz., 39 (1911).

"De Beer, G. R., "The Development of the Vertebrate Skull" (Oxford, 1937 ).

Fuchs, H., Arch. Anat. u. Physiol., Anat. Abt. (1909, Suppl.).

7 Voit, M., Anat. Hefte, 38 (1909).

Bias in the Use of Small-size Plots in Sample Surveys for Yield

SAMPLE surveys for yield of cotton, whest and paddy conducted in recent years all over India (except Bengal) have been carried out on plots of large size varying from $1 / 160$ to $1 / 20$ of an acre ${ }^{1,2}$. In contrast, the plot size used in Britain and the United States is small, of the order of $1 / 4,000$ of an acre 3,4 . In India the small-size plot (area 13.6 sq. ft.) was first used by Hubback and in recent years by Mahal. anobis 5,6

An investigation was carried out in the Moradabad district (area $2,288 \mathrm{sq}$. miles) for comparing different'size plots. The plan of sampling was similar to that used earlier ${ }^{1,2}$, except that in each selected fleld eight plots were marked at random: (a) two equilateral triangular plots of side $33 \mathrm{ft}$. subdivided into three strips by means of lines parallel to the base at distances of $81 \mathrm{ft}$. and $16 \frac{1}{\mathrm{l}} \mathrm{ft}$. from the vertex along the sides; (b) three circular plots of radius $2 \mathrm{ft}$. each; and (c) three circular plots of radius $3 \mathrm{ft}$, each. The triangular plots were marked with the help of chains and pegs and the circular ones with the help of a specially devised apparatus consisting of a peg, a steel tap and a plumb line. The investigation was carried oug, a steel tape and a plumb line. The investigation was carried out by the arily are required to carry out these experiments under official orders.

\begin{tabular}{|c|c|c|c|}
\hline $\begin{array}{l}\text { Size of plot } \\
\text { in sq. } \mathrm{ft} .\end{array}$ & $\begin{array}{l}\text { No. of } \\
\text { plots }\end{array}$ & $\begin{array}{l}\text { Average yield in } \\
\text { maunds per acre }\end{array}$ & $\begin{array}{c}\text { Percentage } \\
\text { over-estimation }\end{array}$ \\
\hline $\begin{array}{c}\text { Irrigated } \\
471.5 \\
117.9 \\
29.5 \\
28.3 \\
12.6 \\
\text { Unirrigated }\end{array}$ & $\begin{array}{r}78 \\
78 \\
78 \\
117 \\
117\end{array}$ & $\begin{array}{l}10 \cdot 10 \\
10 \cdot 58 \\
11 \cdot 69 \\
11 \cdot 60 \\
14 \cdot 38\end{array}$ & $\begin{array}{r}4 \cdot 8 \\
15 \cdot 7 \\
14 \cdot 9 \\
42 \cdot 4\end{array}$ \\
\hline $\begin{array}{c}471 \cdot 5 \\
117 \cdot 9 \\
29 \cdot 5 \\
28 \cdot 3 \\
12 \cdot 6\end{array}$ & $\begin{array}{l}107 \\
107 \\
107 \\
162 \\
161\end{array}$ & $\begin{array}{l}6 \cdot 55 \\
7 \cdot 27 \\
8 \cdot 08 \\
7 \cdot 52 \\
9 \cdot 33\end{array}$ & $\begin{array}{l}11 \cdot 0 \\
23 \cdot 4 \\
14 \cdot 8 \\
42 \cdot 4\end{array}$ \\
\hline
\end{tabular}

The accompanying table shows the results. It will be seen that sma plots (less than 30 sq. ft.) result in a serious over-estimation of yield. The bias diminishes with increase in the size of plot, but even plots of $118 \mathrm{sq}$. ft. are not free from bias. The differences in the yield estim ates are found to be statistically significant. Not only are the results consistent both for irrigated and unirrigated wheat, but also the show the same trend of bias in all the six tehsils in which experiment were carried out. The fleld staff employed was different everywhere.

Yates has previously reported the existence of bias from the use of small-size plots ${ }^{7}$. The reason for over-estimation appears to be the human tendency to include border plants inside the plot. This factor becomes serious when the perimeter of the plot is large in proportion to its area. In another scheme in Madras, a comparison was made between the estimates from 1/20 acre plots and the whole fleld, and the two agreed within the margin of their sampling errors. These results indicate that in India, where crops are unevenly sown, and possibly also in Britain and the United States, small-size plots most probably lead to biased results.

P. V. Sukhatue.

Imperial Council of Agricultural Research,

$$
\text { New Delhi }
$$

1 Panse, V. G., and Kalamkar, R. J., Curr. Sci., 13, 120, 22:3.

'Sukhatme, P. V., Nature, 154, 299 (1944). Proc. Ind. Acad. Sci., B, 21, 328

Cochran, W. G, J, Amer, Stat. Assoc, 34, 492

4 King, A. J., MeCarty, D. E., and MCPeak, M., U.S. Dept. Agric. Bull. 814 .

${ }^{6}$ Hubback, J., Agric. Res. Ind. Pusa, Bull. 166.

Mahalanobis, P. C., Sankhya, 7, 1

Yates, F., Ann. Eug., 6, 2. 